\title{
ADDITIONS TO THE GALL MIDGE FAUNA OF NEW ENGLAND.
}

\author{
By E. P. Felt, \\ Albany, New York.
}

Last year we prepared a list ${ }^{1}$ of 137 New England species, a number being characterized as new. Additional material has been received through the courtesy of Mr. C. W. Johnson of the Boston Society of Natural History, Mrs. A. T. Slosson of New York, and Miss Cora H. Clarke of Boston. Full data as to the origin of the material accompanies each description.

Mr. Johnson captured a specimen of Asphondylia fulvopedalis Felt at Brattleboro, Vt., August 15, 1908, adding thereby another species to the list.

\section{Monardia lateralis sp. nov.}

Male: Length $.75 \mathrm{~mm}$. Antennæ half the length of the body, thickly haired, dark brown; 13- and probably 14-segmented the fifth with a stem one-half the length of the tapering basal enlargement, which latter has a length nearly twice its diameter. Palpi; the first and second segments short, the third twice the length of the second. Mesonotum dark reddish brown. Scutellum, postscutellum and abdomen reddish brown. Halteres and legs mostly fuscous yellowish, the apical portion of the fourth and the fifth tarsal segments reddish brown. Claws strongly curved, finely denticulate, the pulvilli longer than the claws. Genitalia; basal clasp segment short, very broad, truncate distally; terminal clasp segment short, stout, broadly rounded apically and not reaching the median line. Harpes broad, irregular, heavily chitinized posteriorly, with the inner posterior angles produced in slightly curved, stout, conical processes extending in a postero-lateral direction.

Type: Cecid. 1511.

This species runs in our key to M. balsamicola Felt, from which it is easily separated by marked differences in the genitalia. It was received from C. W. Johnson, labeled Boston, Mass., May 10, Owen Bryant.

\section{Monardia multiarticulata sp. nov.}

Female: Length $3 \mathrm{~mm}$. Antennæ extending to the third abdominal segment, thickly haired, yellowish brown, with 29 and possibly more antennal segments, the fifth subsessile, disk-like, with a length about three-fourths its diameter and exceptionally large, irregular stemmed disks. The terminal segments are produced, the stem with a length nearly two-thirds that of the broadly pyriform basal en-

1 Psyche, Vol. XX, pp. 133-47. 
largement. Palpi; the first segment subquadrate, the second with a length four times its diameter, the third a little longer than the second, the fourth a little longer than the third and somewhat dilated. Mesonotum black, sparsely clothed with ferruginous hairs. Scutellum dark brown, postscutellum fuscous. Abdomen brownish yellow, the ovipositor fuscous. Halteres and legs mostly fuscous yellowish, the distal tarsal segment slightly fuscous; claws denticulate, the pulvilli rudimentary. Ovipositor short, the lobes triarticulate, the distal segments suborbicular and rather thickly clothed with long, stout setæ.

Type: Cecid. 1501.

This species is described from a very interesting midge received from Mrs. A. T. Slosson and labeled Franconia, N. H. It is remarkable because of the very large number of antennal segments. This and other characters prevent our referring it to two allied forms, namely C. lignivora Felt and $C$. articulosa Felt.

Monardia rugosa sp. nov.

Female: Length $2 \mathrm{~mm}$. Antennæ extending to the third abdominal segment, thickly haired, light brown; 12 segments, the fifth with a stem three-fourths the length of the tapering basal enlargement, which latter has a length one-third greater than its diameter, bears conspicuous disk like organs near the middle and is conspicuously wrinkled apically; terminal segment produced, with a length fully twice its diameter, the distal half more slender, coarsely and reticulately wrinkled, and with a short, tapering asymmetrical process apically. Palpi; first segment subquadrate, the second ovate, the third smaller, globose, the fourth more than twice the length of the third and slender. Mesonotum reddish brown. Scutellum light purplish brown, postscutellum, abdomen, coxæ and legs mostly fuscous yellowish. Claws rather stout, evenly curved, the pulvilli rudimentary. Submedian ventral glands of the sixth abdominal segment oval. Ovipositor short, triarticulate, the terminal lobes tapering to a narrowly rounded setose apex.

Type: Cecid. 1510.

This midge was received from C. W. Johnson and labeled Hanover, N. H., August 5, 1908. It is easily separated from females previously referred to this species, by the distinct stems of the antennal segments.

Porricondyla novae-angliae sp. nov.

Female: Length $1.75 \mathrm{~mm}$. Antennæ extending to the third abdominal segment, sparsely haired, dark brown, probably 12 and possibly 14 segments, the fifth with a stem one-fourth the length of the cylindrical basal enlargement, which latter has a length three times its diameter; terminal segment missing. Palpi; the first segment stout, with a length three times its diameter, the second one-half longer, more slender, the third a little longer than the second, somewhat dilated, and the fourth one-half longer than the third. Mesonotum shining dark brown. Scutellum red- 
dish brown, postscutellum dark brown. Abdomen dark yellowish brown. Halteres yellowish basally, fuscous apically. Coxæ and femora basally yellowish, the distal portion of femora and the tibiæ mostly dark straw. Tarsi yellowish brown, the posterior pair with the distal portion of the second and the third, fourth and fifth segments whitish. Ovipositor short, the terminal lobes biarticulate, the basal portion narrowly oval, the distal segment fusiform and sparsely setose.

Type: Cecid. 1503.

The midge was received from Mrs. A. T. Slosson and was labeled Franconia, N. H. The structure of the ovipositor serves to separate it at once from all other females referable to this genus.

\section{Porricondyla papillata sp. nov.}

Female: Length $3 \mathrm{~mm}$. Antennæ extending to the fourth abdominal segment, ratherly thickly haired, yellowish, the distal segments brownish; 14 segments, the fifth with a short stem, the cylindrical basal enlargement with a length about three times its diameter. Palpi; the first segment long, with a length four times its diameter, the second short, irregular, the third nearly twice the length of the second, the fourth slender and fully twice the length of the third. Mesonotum reddish brown. Scutellum brownish yellow, postscutellum a little darker. Abdomen sparsely haired, yellowish brown. Halteres brownish yellow. Coxæ and femora mostly pale straw. Tibiæ a little darker, the tarsi yellowish brown. Claws stout, strongly curved, unidentate, the pulvilli longer than the claws. Ovipositor short, indistinct in the preparation, apparently being covered by two rounded lateral plates, each with a large, thick group of papillæ sublaterally; each papilla subconical, hirsute and apically with a falcate process.

Type: Cecid. 1502.

The midge characterized above was received from Mrs. A. T. Slosson and labeled Mount Washington. It is a large form easily separated from all other midges known to us, by the two large sublateral groups of papillæ at the posterior extremity.

\section{Lasiopteryx crispata sp. nov.}

Larva: Length $2.5 \mathrm{~mm}$., moderately stout, yellowish orange. Head rather narrowly triangular, apex narrowly rounded. Antennæ biarticulate, tapering, with a length about three times the diameter; breastbone well chitinized, bidentate, the shaft tapering posteriorly and somewhat expanded at its extremity. Skin coarsely shagreened, posterior extremity broadly rounded, slightly bilobed.

Female: Length $1 \mathrm{~mm}$. Antennæ one-half the length of the body, sparsely haired, fuscous, the two basal segments yellowish; 13 and probably 14 subsessile segments, the fifth cylindric, with a length about $2 \frac{1}{2}$ times its diameter and with a moderately thick subapical group of long, curved s;etæ near the ventral third. Palpi; first segment irregular, the second with a length three times its diameter, the third and 
fourth, each as long as the second and successively more slender. Face pale yellowish; eyes black. Body yellowish. Mesonotum fuscous, the submedian lines with broad, rather coarse scalelike hairs. Abdomen clothed with fuscous scales and a few long hairs, the incisures yellowish. Wings hyaline, the membrane with numerous narrow, curved scales; costa dark brown. Halteres black. Coxæ yellowish; femora basally pale yellowish, the tibiæ and tarsi gradually darker to dark brown. Claws slender, strongly curved, unidentate, the pulvilli about half the length of the claws. Ovipositor short, the lobes narrowly oval and thickly setose.

Type: Cecid. a2341.

A single female was reared August 22, 1912, from a jar containing oval, yellowish blister galls on Oakesia sessilifolia collected by Miss Cora H. Clarke at Magnolia, Mass. It is possible that this insect was not an inhabitant of this gall. The generic reference is also provisional.

\section{Schizomyia speciosa sp. nov.}

Female: Length $2 \mathrm{~mm}$. Antennæ as long as the body, thickly haired, reddish brown, the segments distally with yellowish hairs, these producing an indistinct yellowish annulation; 14 segments, the fifth with a length about five times its diameter, the 12th with a length one-half greater than its diameter, the 13th with a length equal its diameter, the 14th disk-like. Palpi; first segment irregular, the second with a length about three times its diameter, the third with a length four times its diameter, somewhat dilated, the fourth one-half longer than the third and dilated. Mesonotum yellowish brown, the submedian lines thickly clothed with long, yellowish hairs. Scutellum and postscutellum yellowish. Abdomen sparsely haired, dark brown. Wing membrane thickly clothed with dark scales, almost subhyaline, there being a distinct spot near the tip of the third vein, one at the apex of the fifth and another along its posterior fork. Halteres dark brown, the distal portion of the stem yellowish, the apical half of the club white. Coxæ yellowish brown. Legs mostly dark brown, the anterior and middle femora narrowly annulate in the middle with yellowish, the posterior femora with the basal half white; the bases of the tibiæ, the first tarsal segment and the distal half of the second, third and fourth and the basal portion of the fifth white. The bands on the posterior tarsi yellowish and broader, there being on the third and fourth tarsal segments only a narrow, brown annulation near the basal third. Claws moderately stout, evenly curved, simple, the pulvilli rudimentary. Ovipositor when extended probably as long as the body, the aciculate part narrowly chitinized ventrally and approaching the condition found in Asphondylia; the ventral plate well developed.

Type: Cecid. 1507.

The striking midge described above was received from Mrs. A. T. Slosson and labeled Franconia, N. H. It is allied to S. rivinoe Felt from which it may be easily separated by its somewhat larger 
size, the darker color of the abdomen, the more distinctly and broadly white-banded posterior tarsi and the relatively longer antennal segments.

\section{Hormomyia proteana sp. nov.}

Male: Length $5 \mathrm{~mm}$. Antennæ extending to the third abdominal segment, sparsely haired, fuscous yellowish; 14 segments, the fifth subsessile, subcylindric, with a broad constriction at the basal third; the eighth and following rather plainly binodose, with stems about three-fourths and one-half their diameters, respectively. The three circumfili irregular and apparently forming double or nearly double bands. Terminal segment with a narrow constriction dividing the globose basal enlargement and the fusiform distal swelling. Palpi probably small (indistinct in the preparation) and presumably uni- or biarticulate. Mesonotum shining black. Scutellum and the lateral and posterior margins of the thorax yellowish, the postscutellum dark brown. Abdomen mostly yellowish brown. Halteres yellowish. Coxæ and legs fuscous yellowish; claws simple, the pulvilli rudimentary. Genitalia; basal clasp segment long, moderately stout; terminal clasp segment long, stout; dorsal plate broadly, deeply and triangularly emarginate, the lobes moderately slender and narrowly rounded apically; ventral plate moderately long, broad, broadly rounded.

Type: Cecid. 1521.

The large midge described above was collected by Mr. C. W Johnson at Auburndale, Mass., May 28. It is easily distinguished from other large Hormomyias by the antennal segments and particularly by the cylindric character of the basal ones of the flagellum.

\section{Parallelodiplosis cinctipes sp. nov.}

Male: Length $1 \mathrm{~mm}$. Antennæ one-half longer than the body, thickly haired, pale straw; 14 segments, the fifth with stems 2 and $2 \frac{1}{2}$ times their diameters, respectively. Circumfili moderately long. Palpi; first segment short, broadly oval, the second quadrate, with a length more than twice its width, the third a little shorter and more slender than the second, the fourth one-half longer than the third, dilated. Mesonotum yellowish brown. Scutellum yellowish, postscutellum and abdomen yellowish brown. Wings subhyaline, with indistinct fuscous areas near the distal fourth, before and behind the third vein, near the middle, on the margin between the third and fifth veins, and on the fork of the fifth and at the basal third an indistinct diffused area extending nearly across the wing. Halteres yellowish transparent. Legs dark brown, broadly banded with white as follows: Femora, the apical half; tibiæ, a broad band near the basal third and the apical half; tarsi, the apex of the first segment and the basal two thirds of the second, the basal two thirds of the third and most of the fourth and fifth, the banding being more striking on the posterior than on the anterior or mid legs. Genitalia; basal clasp segment moderately long, stout, with a distinct tooth at the internal basal 
angle; terminal clasp segment long, rather stout; dorsal plate broad, deeply and roundly emarginate, the lobes narrowly rounded; ventral plate moderately long, broad, narrowly rounded apically; style long, the basal two thirds swollen, the apex dilated.

Type: Cecid. 1522.

The well marked midge described above was reared in May, 1908, by Mr. C. A. Frost, Framingham, Mass., from dead twigs of Rhus vernix. The specimens were placed at our disposal through the courtesy of Mr. C. W. Johnson.

\section{EXCHANGE COLUMN.}

Will name and return species in certain families of Coleoptera. Buprestidæ especially desired.-C. A. Frost, 26 Pond Street, South Framingham, Mass.

Wanted. Insects from ant-nests, with specimens of the ants, from any part of the world. Will give Coleoptera, Diptera and Hymenoptera from any Western United States.-W. M. Mann, Bussey Institution, Forest Hills, Mass.

Will exchange for Geometridæ from any section of North America, or identify material for privilege of retaining examples.-L. W. Swett, 501 Washington Street, Room 44, Boston, Mass.

Will exchange insects of various orders for Parasitic Hymenoptera from any part of the world.-C. T. Brues, Bussey Institution, Forest Hills, Mass.

Wanted, for cash or exchange, living material of Lucilia from the Southern States; also living material of Cynomia mortuorum from Europe and any other species of Cynomia except Cadaverina. Will give directions for shipment.-P. W. Whiting, Bussey Institution, Forest Hills, Mass.

Carabus chamissonis and other rare Coleoptera for Dytisidæ not in my collection. -F. W. Dodge, Melrose Highlands, Mass.

Wanted. Ants from all parts of the world.-W. M. Wheeler, Bussey Institution, Forest Hills, Mass.

I pay cash or give American and exotic insects in exchange for fertile eggs of Catocala spp., living Catocla 우 우 (captured specimens only), hibernating pupæ and larvæ of any other group of Lepidoptera.-William Reiff, 366 Arborway, Jamaica Plain, Boston, Mass.

Florida insects of all orders, also Fish, Batrachians, Reptiles, Shells and Marine Invertebrates sold by A. G. Reynolds, Gulfport, Florida.

New England Orthoptera identified. I wish to examine adult orthoptera of all families from all parts of New England. Material will be identified for the privilege of retaining desired examples, for which good exchanges will be given, subject to approval of owner.-A. P. Morse, Wellesley College, Wellesley, Mass.

The undersigned will greatly appreciate receiving records of New Jersey species not listed in Smith's Insects of New Jersey.-Harry B. Weiss, 272 Hale St., New Brunswick, N. J.

Offered for cash, but exchange preferred. Fitch and early Illinoís reports; Insect Life; Harris's Insect: many others.-J. E. Hallinen, Cooperton, Okla. 

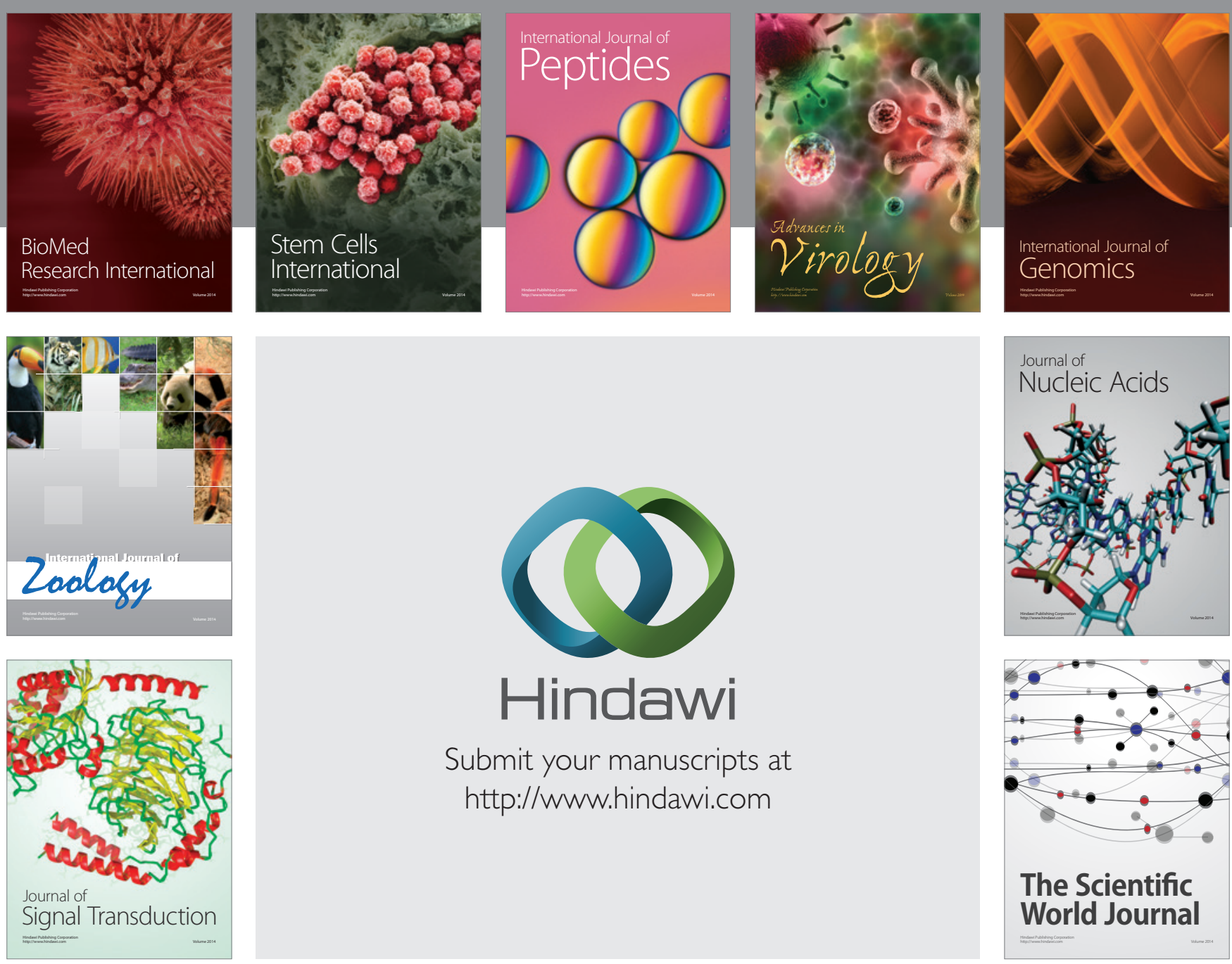

Submit your manuscripts at

http://www.hindawi.com


The Scientific World Journal
